\title{
UPLATNENIE POJMOVÝCH MÁP V GEOGRAFII NA ZÁKLADNEJ ŠKOLE
}

\author{
Alfonz Gajdoš, Dominika Majcherová
}

\begin{abstract}
This work refers to possibilities of using concept maps in a teaching process. We focus on using them from the perspective of a pupil and especially from the perspective of a teacher. The aim is to give to a teacher some instructions for using concept maps in different phases of a class, for making notes, for the work with some text and others. Some methodical drafts of classes were created for this purpose. Pupils of the $6^{\text {th }}$ year were our research cohort. In the empiric part, using methods such as pedagogical experiment, analysis of activity products and questionnaire, we try to point to effectivity of using concept maps in classes in comparison with classical teaching methods in geography classes. The questionnaire is concentrated on attitudes and opinions of pupils to teaching with concept maps. The results give information for the field of praxis. The work can be used as a simple manual and inspiration for the teachers who would like to apply this method in their classes.
\end{abstract}

Keywords: geography, concept maps, innovative methods, using of concept maps

\section{Úvod}

V súčasnej dobe sa čoraz väčší dôraz kladie na aplikovanie inovatívnych metód vo vyučovaní geografie. Pojmové mapy sú jednou z vyučovacích metód, ktoré sa začali využívat' na vyučovaní už koncom druhej polovici 20. storočia. Patria medzi aktivizujúce metódy, ktorých podstatou je plánovat', organizovat' a riadit' vyučovanie geografie prostredníctvom vlastnej, poznávacej aktivity žiakov. Pojmové mapy sú nástrojom tvorivého myslenia, pri ktorých nie je dôležitý len výsledok, ale aj proces jej tvorby. Ciel'om príspevku bolo aplikovat' metodické návrhy vyučovacích hodín geografie s použitím pojmových máp a zhodnotit' ich efektívnost' využitia v porovnaní s klasickými vyučovacími metódami, ako aj zistit' názory žiakov na využitie pojmových máp vo vyučovaní geografie.

\section{Teoreticko-metodické východiská}

V odbornej literatúre sa stretávame s rôznymi názvami grafického usporiadania klúčcových prvkov učiva. Autori uvádzajú termíny pojmové mapy, mentálne mapy, myšlienkové mapy, kognitívne mapy, vedomostné mapy a pod. (Drbohlav, 1991, Fisher, 1997, Buzan, 2007, Prokša, 2007, Prokša a kol., 2008, 
Gregorová, 2009, Černý, Černá, 2011, Karolčík, Murtinová, 2013, 2014a, 2014b a i.).

V geografii môže l'ahko dôjst' k nejasnostiam, pretože pojem mapy evokuje na prvom mieste mapu ako kartografické dielo. Preto by bolo vhodnejšie používat' termín pojmové schémy a termín pojmová mapa ponechat' pre špecifickú formu pojmovej schémy, v ktorej je do pojmovej štruktúry pridávaná aj priestorová charakteristika, ako je to v geografickej mape (Karolčík, Murtínová, 2014b). Medzi odborníkmi neexistuje terminologická zhoda v chápaní rôznych označení zachytenia myšlienkových konceptov do grafickej štruktúry súvisiacich pojmov a označením vzt'ahov a väzieb medzi nimi. Označenia pojmová, mentálna alebo myšlienková mapa sa chápu ako synonymá.

V školských rokoch 2016/2017 a 2017/2018 bol realizovaný prieskum na Cirkevnej ZŠ Romualda Zaymusa v Žiline, zúčastnilo sa ho 100 žiakov 6. ročníka (24 až 25 žiakov v každej triede). Pre porovnanie efektívnosti využitia pojmových máp s efektívnost’ou tradičnej metódy vyučovania sa použili metódy experimentu, komparácie a analýzy pojmových máp žiakov. Na základe prospechu z geografie v 5. ročníku boli vytvorené dve skupiny žiakov - experimentálna a kontrolná. V podmienkach školy nebolo možné vytvorit’ dve rovnocenné skupiny na základe priemeru, lebo medzi nimi existuje štatisticky významný rozdiel. V tomto prípade sa stala experimentálnou skupinou trieda, ktorá mala slabší prospech (Turek 1996). $\mathrm{Na}$ záver prieskumu sa prostredníctvom dotazníka zist'ovali postoje a názory žiakov na využitie pojmových máp.

Na základe stanovených ciel'ov boli postavené nasledujúce hypotézy:

$\mathrm{H}_{1}$ - žiaci experimentálnej skupiny napriek horšiemu priemeru z geografie dosiahnu lepšie výsledky v pedagogickom experimente ako žiaci kontrolnej skupiny,

$\mathrm{H}_{2}$ - žiaci, ktorí pracujú s pojmovými mapami si zapamätajú viac pojmov ako tí, ktorí sa učia klasickými vyučovacími metódami (výklad učitela), $\mathrm{H}_{3}$ - žiaci, ktorí si vytvárajú poznámky vo forme pojmovej mapy si zapamätajú viac pojmov ako tí, ktorí si robia lineárne poznámky,

$\mathrm{H}_{4}$ - žiaci využívajú pojmové mapy viac na písanie poznámok ako na spracovanie textu,

$\mathrm{H}_{5}$ - žiaci vytvárajú pojmové mapy viac na predmete geografia ako na iných predmetoch,

$\mathrm{H}_{6}$ - žiaci viac uprednostňujú papierové pojmové mapy ako elektronické,

$\mathrm{H}_{7}$ - žiaci uprednostňujú pri tvorbe pojmovej mapy viac prácu v skupine ako samostatnú prácu, prácu vo dvojici alebo ked' ich vytvára učitel'.

$\mathrm{Na}$ overenie hypotéz $\mathrm{H}_{1}-\mathrm{H}_{3}$ bola požitá metóda pedagogického experimentu, kde sa porovnávali výsledky experimentálnej a kontrolnej skupiny. Využila sa aj metóda krátkodobého pozorovania. Ňou sa zist’ovala spolupráca žiakov pri vytváraní pojmovej mapy v skupine pri práci s textom. Na overenie hypotéz $\mathrm{H}_{4}-\mathrm{H}_{7}$ bol požitý elektronický dotazník. 
Hlavnou výskumnou metódou bol dvojskupinový pedagogický experiment realizovaný v prirodzených podmienkach. Požitie experimentálnej a kontrolnej skupiny umožňuje manipulovat' s premennou (Gavora, 2000). V našich podmienkach bol nezávisle premennou systém vyučovania $\mathrm{v}$ experimentálnej skupine, v kontrolnej skupine vyučovanie klasickými metódami (výklad, rozhovor, diskusia, riešenie úloh a pod.). Závisle premennou boli výkony žiakov (vedomosti a postoje). Po realizácii pedagogického experimentu sa overil jeho výsledok odmeraním závisle premennej u oboch skupín žiakov. Výsledné meranie (posttest) bolo zadávané v rovnakom čase a za rovnakých podmienok. Prostredníctvom posttestu sa zist'oval vplyv nezávisle premennej na závisle premennú.

\section{Príprava, realizácia a výsledky práce}

Hlavným produktom tvorby žiakov boli pojmové mapy. $\mathrm{Na}$ ich vyhodnotenie sa použiva kvantitatívna analýza pomocou skórovania (Prokša a kol. 2008, Jirásek 2015). Na tento účel bol vytvorený skórujúci systém (pojmové a krížové spojenia, hierarchia, príklady, farby, chyby) s názvom MMAR (mind map assessment rubric).

Pre potreby prieskumu bola navrhnutá kvantitatívna a čiastočne aj kvalitatívna analýza zodpovedajúca mentálnej úrovne žiakov 6. ročníka. Vlastný systém analyzovania pojmových máp bol uplatnený pri téme povrch Ázie. Mal nasledovný postup:

a) bola vytvorená vlastná (autorská) pojmová mapa s pojmami, ktoré sa očakávajú, že sa ich žiaci naučili alebo si ich zapamätali,

b) bola vytvorená prehl'adná tabul'ka na zapisovanie pojmov, ktorá obsahovala počet pojmov zhodných s vlastnou (autorskou) pojmovou mapou, počet pojmov súvisiacich $\mathrm{s}$ témou a iné pojmy nesúvisiace $\mathrm{s}$ témou,

c bola navrhnutá metodika na zapisovanie pojmov do tabul'ky:

- každé slovo, resp. slovné spojenie za považovalo za jeden pojem,

- všetky pojmy majú rovnakú váhu (sú rovnocenné),

- súvisiace pojmy bezprostredne vychádzajúce z témy (žiaci sa slová neučili, neboli spomenuté na vyučovacej hodine. Mohli ich vediet' na základe vlastného učenia sa alebo pri práci s mapou, napr. na vyučovacej hodine sa učili štyri nížiny, ale uviedli aj názov piatej. Išlo teda o súvisiaci pojem. V tomto prípade číslo štyri bolo zaradené do skupiny pojmov zhodných s autorskou mapou a číslo jedna do skupiny pojmov súvisiacich s témou. Do iných pojmov nesúvisiacich s témou boli zaradené aj pojmy, ktoré žiakom evokovali hlavný pojem.

Pri téme obyvatel'stvo Ázie bol ešte uplatnený vlastný nasledovný postup:

a) bodovo sa ohodnotila vizuálna a estetická stránka pojmovej mapy (bodovacia škála $1-5$ ),

b) bodovo sa zhodnotilo použitie pojmov a pochopenie textu $(0-15$ bodov), 
c) bola vytvorená tabul'ka s celkovým počtom bodov, ktoré jednotlivé skupiny získali.

Samotnému prieskumu predchádzala príprava metodických návrhov vyučovacích hodín s využitím pojmových máp:

- na tvorbu poznámok,

- na opakovanie v skupinách,

- na naučenie sa nového učiva,

- na prácu s textom a prácou $\mathrm{v}$ skupine.

Vo všetkých prípadoch mal posttest formu tabul'ky, do ktorej si obe skupiny zapisovali pojmy, ktoré si zapamätali pri využití pojmových máp alebo klasických metódach. V záverečnej fáze prípravy sme vytvorili elektronický dotazník prostredníctvom Google dokumentov s jedenástimi otázkami. Boli použité zatvorené otázky s jednoduchým alebo aj viacnásobným výberom. Väčšina otázok boli polouzavreté položky. Dotazníkom sme overovali hypotézy $\mathrm{H}_{4}-\mathrm{H}_{7}$. Všetci zainteresovaní žiaci dostali link s dotazníkom a mohli ho vyplnit’ len raz.

Pred začiatkom práce s pojmovými mapami bola jedna vyučovacia hodina venovaná nácviku práce sa zameraním na vysvetlenie základných pravidiel tvorby pojmovej mapy na papier aj v programe XMind a MindMaple Lite. Následne bolo v školských rokoch 2016/2017 a 2017/2018 zrealizované vyučovanie s využitím pojmových máp. V závere oboch školských rokov sa zhodnotil priebeh vyučovacích hodín a vyplnili sa dotazníky.

Prvý metodický návrh (južná Afrika) bol zameraný na využitie papierových pojmových máp na tvorbu poznámok $\mathrm{z}$ danej témy. $\mathrm{V}$ oboch školských rokoch sa vyučovala téma južná Afrika nasledovne:

- kontrolná skupina sa učila o téme prostredníctvom výkladu, metódou rozhovoru, práce s mapou (atlas, nástenná), učebnicou a pracovným listom, pričom si žiaci vytvárali klasické lineárne poznámky,

- experimentálna skupina vytvárala vlastné papierové pojmové mapy na hodine, príp. niektorí si poznámky dokončili doma, využívali školské atlasy a nástennú mapu.

Žiaci v experimentálnej skupine si počas vyučovacej hodiny vytvorili rôznorodé poznámky v podobe pojmových máp. Na začiatku boli oboznámení s osnovou hodiny a mohli si hned' v úvode zapisovat' kl'účové pojmy. Mapu vytvárali súbežne počas celej vyučovacej hodiny, preto nemali čas kreslit'. Niektoré mapy boli vel'mi strohé a jednoduché, niektoré písali iba základné pojmy a žiadne informácie navyše si do svojej pojmovej mapy nezaznamenali. Vytváranie vlastných poznámok bolo pre slabších žiakov náročné. Nevedeli, ktoré pojmy sú pre nich podstatné. Celkove hodnotíme, že pre žiakov bolo náročné z počúvaného textu vybrat' podstatné informácie. Pre porovnanie efektívnosti využitia pojmovej mapy a úspešnosti zapamätania pojmov bol vypracovaný posttest na doplňovanie pojmov. Žiaci oboch skupín dopíňali pojmy týkajúce sa južnej Afriky, ktoré sa naučili na predchádzajúcej hodine. 
Experimentu sa v oboch školských rokoch zúčastnilo 96 žiakov. Porovnali sa výsledky oboch skupín a zistilo sa, že žiaci experimentálnej skupiny napriek horšiemu priemeru $\mathrm{z}$ geografie dosiahli v postteste lepšie výsledky ako žiaci kontrolnej skupiny (potvrdenie hypotézy $\mathrm{H}_{1}$ ). Zároveň sa potvrdila hypotéza $\mathrm{H}_{3}$, pojmové mapy sa osvedčili ako efektívny spôsob tvorenia poznámok. Žiaci, ktorí si vytvárali poznámky vo forme pojmovej mapy si zapamätali viac pojmov, ako žiaci robiaci si klasické lineárne poznámky. Pojmy si žiaci zapamätali lepšie ako pri výklade alebo rozhovore. Viac ako 51 \% žiakov v dotazníku uviedlo, že radi využívajú pojmové mapy na tvorbu poznámok. Pre 3 žiakov z experimentálnej skupiny to však nebol efektívny nástroj na tvorbu poznámok a zapamätanie si.

Tvorba pojmovej mapy na tvorbu poznámok podporuje zodpovednejší prístup žiaka. On vie, že nikto iný okrem neho, mu poznámky nevytvorí. Nemôže si ich ani požičat' od iného spolužiaka, lebo každá vzniknutá pojmová mapa je originálne dielo.

Druhý metodický návrh (povrch Ázie) bol zameraný na využitie papierových pojmových máp na opakovanie prostredníctvom skupinovej práce (4 6 žiakov). Ciel'om bolo zistit' efektívnost' využitia pojmovej mapy pri opakovaní pomocou analýzy pojmových máp vytvorených žiakmi. Téma bola odučená klasickými vyučovacími metódami. Žiaci v experimentálnej skupine boli rozdelení do piatich skupín. Každá skupina vytvorila originálnu pojmovú mapu, ktorá prezentovala to, čo si zapamätali o povrchu Ázie. Väčšina z nich najskôr umiestnila do stredu hlavný pojem a potom ho postupne rozvetvovali. Niektorí ostali len pri základnom vetvení. Žiaci sa držali pravidiel a využivali aj farebné obrázky. Zapamätali si pojmy nielen na danú tému, ale dokázali do posttestu napísat' ovel'a viacej pojmov, ktoré sa učili predtým (napr. členitost' Ázie, poloha). Jedna zo skupín si dokázala prostredníctvom pojmových máp spomenút' až na vyše $90 \%$ pojmov.

Celkove hodnotíme využitie pojmových máp ako vhodný spôsob pri opakovaní učiva. Žiaci si hravou formou zopakovali naučené vedomosti, diskutovali o nich v skupine, učili sa ich správne zatriedit'. V žiadnej skupine nevedeli pojmy všetci, ale spolupráca medzi nimi pomáhala aj zaostávajúcim žiakom.

Tretí metodický návrh (vodstvo Ázie) využil elektronickú pojmovú mapu na naučenie sa nového učiva. V oboch školských rokoch sa vyučovala téma vodstvo Ázie nasledovne:

- kontrolná skupina sa učila o téme prostredníctvom výkladu, metódou rozhovoru, práce s mapou, učebnicou a pracovným listom, pričom si žiaci vytvárali klasické lineárne poznámky,

- experimentálna skupina vytvárala pojmovú mapu na danú tému $\mathrm{v}$ programe XMind a MindMaple, poznámky mali vo forme elektronickej pojmovej mapy. Žiaci používali jeden školský notebook, ktorý bol napojený na dataprojektor. Žiaci sa striedali pri práci s notebookom, ostatní sledovali dataprojektor. Vyučovacia hodiny trvala 45 minút. 
Experimentálna skupina v školskom roku 2016/2017 na vytvorenie pojmovej mapy využila program MindMaple. Na hárku bol napísaný hlavný pojem (vodstvo Ázie) a na okraji boli vložené obrázky. Žiaci si do notebooku zapisovali pojmy do pracovného hárku programu. Spočiatku sa žiaci t’ažko sústred'ovali na paralelné počúvanie výkladu učitel'a, prácu s atlasom, nástennou mapou zapisovanie pojmov a sledovanie dataprojektoru. Postupne však menili štruktúru pojmovej mapy. K pojmom $\mathrm{v}$ závere priradili vhodné obrázky a upravili hrúbku čiar a rozmiestnenie pojmov. Boli aktívni, viacerí si opakovane vyskúšali prácu s programom.

Experimentálna skupina v školskom roku 2017/2018 pracovala na tvorbe pojmovej mapy v programe XMind podobným systémom tak, že do mapy postupne dopíňala pojmy, vetvila ich a upravovala mapu do finálnej podoby. Žiaci kontrolnej aj experimentálnej skupiny $\mathrm{v}$ oboch školských rokoch vyplnili po vyučovacej hodine posttest. Dosiahli rôzne počty bodov (od maximálneho počtu 18 až po 0 bodov). V experimentálnej skupine (50 žiakov) dosiahlo maximálny počet bodov $16 \%$ žiakov. Vel'mi dobré výsledky dosiahli aj žiaci z kontrolnej skupiny (47 žiakov). Maximálny počet bodov získalo $13 \%$ žiakov. Pri počte bodov 17 dosiahli lepší výsledok žiaci kontrolnej skupiny.

Hypotézu $\mathrm{H}_{1}$ nemôžeme v tomto prípade s určitost'ou potvrdit'. Žiaci experimentálnej skupiny napriek horšiemu priemeru z geografie dosiahli lepšie výsledky v počte bodov 18,16 a 15 , ale rozdiely medzi nimi neboli vel'mi výrazné. Domnievame sa, že keby sme spojili hodnotenie posttestu s klasifikáciou, známku 2 by dosiahli žiaci oboch skupín. Napriek tomu, využitie pojmových máp malo pri experimentálnej skupine zmysel. Darilo sa jej zapamätat' si viac pojmov ako kontrolnej skupine.

Štvrtý metodický návrh (obyvatel'stvo Ázie) bol zameraný na využitie pojmovej mapy na prácu s textom a prácou v skupine. Ciel'om nebolo zistit', kol'ko pojmov žiaci experimentálnej skupiny použijú, ale či budú vediet' z textu vytvorit' pojmovú mapu reflektujúcu obsah textu. Bol vytvorený metodický návrh dvoch vyučovacích hodín. Na prvej hodine mali žiaci prečítat' text a vytvorit' pojmovú mapu. Obsah druhej hodiny tvorila diskusia o téme, hodnotenia pojmových máp a práce $\mathrm{v}$ skupinách.

V školskom roku 2016/2017 pracovalo v experimentálnej triede 5 skupín. Dve skupiny sa dohodli na prečítaní textu individuálne pre každého člena skupiny a potom spoločne vytvoria pojmovú mapu. Vo zvyšných skupinách jeden čítal a ostatní počúvali. Prečítanie dvojstranového textu im trvalo len niekol'ko minút. V dvoch skupinách začali hned' o téme diskutovat'. Ostatné začali tvorit' papierovú pojmovú mapu. Ako hlavný pojem žiaci umiestňovali do stredu mapy obyvatel'stvo. Pojmové mapy obsahovali d’alšie pojmy (politika jedného diet’ata, najludnatejšie krajiny, národy, jazyky, náboženstvá, rasy). Na nasledujúcej vyučovacej hodine dostala každá skupina časový priestor 5 minút na prezentovanie svojej pojmovej mapy. V niektorých skupinách rozprával vedúci, v iných sa 
zapájali všetci. Po ich prezentácii nasledovala diskusia. Z diskusie vyplynulo, že žiakov zaujala napr. téma politiky jedného diet’ata. Na základe diskusie bolo zistené, že žiaci textu porozumeli.

V školskom roku 2017/2018 v experimentálnej skupine si každý žiak individuálne prečítal text na tému obyvatel'stvo Ázie. Oproti predchádzajúcemu školskému roku žiakom dlhšie trvalo čítanie textu. Nevedeli s kým budú v skupine, preto mali väčší pocit zodpovednosti k pochopeniu textu. Na základe žrebovania vzniklo 5 skupín. Pozorovaním sa zistilo, že väčšinou si žiaci zvolili jedného zapisovatel'a (pravdepodobne kvôli lepšej estetickej stránky mapy). V druhej vyučovacej hodine bola prezentácia. Jedna skupina však princíp pojmovej mapy nepochopila, $\mathrm{k}$ hlavnému pojmu vypisovala celé vety. Opät' ako v predchádzajúcom školskom roku aj ich zaujala politika jedného diet’ata, potom náboženstvá.

Žiaci pochopili text, vedeli vybrat' kl'účové pojmy a na ich základe vytvorit' pojmové mapy. Mapy boli prehl'adné, čitatel'né a farebné, obsahovali všetky pojmy, ktoré z textu vyplývali. Najväčší problém mala jedna skupina, ktorá do mapy Ázie napísala celé vety z textu. V školskom roku 2017/2018 boli vytvorené zaujímavejšie a premyslenejšie mapy aj s obrázkami. Bolo to z dôvodu, že žiaci už predtým tvorili pojmové mapy a $\mathrm{v}$ tejto činnosti sa zdokonalili.

Tvorba pojmovej mapy z textu je vysoko prínosná metóda umožňujúca napomáhaniu čitatel'skej gramotnosti. Učí žiakov zodpovednosti a tímovej spolupráci. Dôležitá je ponuka textu, ktorá musí mat' zaujímavý obsah základného a rozširujúceho učiva. Prostredníctvom textu, pojmovej mapy a práci v skupine sa napíňa obsahový a výkonový štandard.

V mesiaci apríl voboch školských rokoch sa metódou dotazníka v elektronickej podobe overovali hypotézy $\mathrm{H}_{2}, \mathrm{H}_{4}, \mathrm{H}_{5}, \mathrm{H}_{6}$ a $\mathrm{H}_{7}$. Dotazník vyplnilo 47 žiakov experimentálnej skupiny.

\section{Záver}

V predmete geografia sa dajú pojmové mapy využit' pri vyučovaní fyzickej, humánnej a regionálnej geografie. Učitel' môže riadit' tvorbu pojmovej mapy viacerými spôsobmi. Pri vyššom stupni riadenia učitel' poskytne žiakom hlavný pojem, naznačí vetvy, d'alšie pojmy a pomáha im pri tvorbe až do dokončenia mapy. Č́m viac sa znižuje stupeň riadenia, tým viac sa prenáša aktivita a iniciatíva na žiaka. Učitel' by mal viest' žiakov $\mathrm{k}$ samostatnosti a tvorbe individuálnych pojmových máp.

Prvý metodický návrh (južná Afrika) využil pojmové mapy na tvorbu poznámok. Žiaci experimentálnej skupiny dosiahli v postteste lepšie výsledky ako žiaci kontrolnej skupiny. Potvrdila sa hypotéza $\mathrm{H}_{3}$. Tvorba poznámok vo forme pojmovej mapy je pre žiakov náročná, vyžaduje ich sústredenost'. Viac ako $51 \%$ žiakov v dotazníku však uviedlo, že radi využívajú pojmové mapy na tvorbu poznámok. 
Druhý metodický návrh (povrch Ázie) využil pojmové mapy na opakovanie v skupinách. Ciel'om bolo zistit' efektívnost' využitia pojmovej mapy pri opakovaní pomocou analýzy pojmových máp žiakov. Každá skupina vytvorila originálnu mapu, ktorá prezentovala zapamätané pojmy. $Z$ výsledkov vyplynulo, že žiaci sa zapamätali pojmy nielen na danú tému, ale ovládali aj d’alšie pojmy, ktoré sa učili na predchádzajúcich hodinách. Potvrdila sa hypotéza $\mathrm{H}_{2}$. Pri opakovaní učiva je vysoko efektívne využit' pojmové mapy.

Tretí metodický návrh (vodstvo Ázie) využil elektronickú pojmovú mapu na naučenie sa nového učiva. V pedagogickom experimente sa porovnávali výsledky experimentálnej a kontrolnej skupiny. Žiaci kontrolnej skupiny získali lepšie výsledky v počte bodov, avšak rozdiely medzi skupinami neboli natol'ko výrazné, aby sa hypotéza $\mathrm{H}_{1}$ potvrdila. Zo záverov vyplýva, že žiaci sa nové učivo naučia pomocou pojmových máp rovnako dobre ako pomocou klasických vyučovacích metód.

Štvrtý metodický návrh (obyvatel'stvo Ázie) bol zameraný na využitie pojmovej mapy na prácu s textom a prácou v skupine. Pojmové mapy všetkých skupín odrážali pochopenie textu. Jedna skupina napriek pochopenia textu nevytvorila pojmovú mapu v pravom slova zmysle (uvedené celé vety). Žiaci v dotazníku uviedli, že sa im tieto vyučovacie hodiny páčili zo všetkých hodín najviac.

Elektronický dotazník bol zameraný na overovanie hypotéz $\mathrm{H}_{4}, \mathrm{H}_{5}, \mathrm{H}_{6}$ a $\mathrm{H}_{7}$, Zist’ovali sa postoje a názory žiakov k pojmovým mapám, Obsahoval 11 otázok, prvé tri otázky boli všeobecného charakteru (zistenie pohlavia, obl'úbenosti predmetu geografia, úroveň zručnosti vytvorit' pojmovú mapu).

Štvrtá otázka zistovala využitie pojmových máp z pohl'adu žiakov, ktorí mohli označit' viacero odpovedí. Hypotéza $\mathrm{H}_{4}$ sa nepotvrdila (žiaci využívajú myšlienkové mapy viac na písanie poznámok ako na spracovanie textu, vytváranie projektov, prípravu na test, na opakovanie pred písomkou). Najviac žiakov (55\%) sa vyjadrilo, že pojmové mapy využívajú pri príprave na test, potom na písanie poznámok $(51 \%)$ a opakovanie pred písomkou $(40 \%)$. Žiaci uprednostňujú vytváranie vlastných papierových pojmových máp ako prípravu pred testom.

Piata otázka vdotazníku potvrdila hypotézu $\mathrm{H}_{2}$ (žiaci, ktorí pracujú s pojmovými mapami si zapamätajú viac pojmov ako tí, ktorí sa učia klasickými vyučovacími metódami), aj ked'už bola viac-menej overená počas realizácie druhého metodického návrhu (povrch Ázie). Z výsledkov ankety vyplynulo, že 66 \% žiakov si vie pojmy lepšie zapamätat' s využitím pojmových máp, 26 \% žiakov nevedelo posúdit' prínos pojmových máp k zapamätaniu si pojmov, vyše $8 \%$ uviedlo, že im mapy nepomáhajú $\mathrm{k}$ lepšiemu zapamätaniu pojmov.

Šiesta otázka slúžila na overenie hypotézy $\mathrm{H}_{6}$ (žiaci viac uprednostňujú papierové pojmové mapy ako elektronické). Zistilo sa, že žiaci pracujú rovnako radi s oboma mapami (skoro $43 \%$ ), potom nasledujú papierové (34 \%) a nakoniec elektronické pojmové mapy (vyše $23 \%$ ). Hypotéza $\mathrm{H}_{6}$ sa týmto potvrdila len 
čiastočne. Výhody papierovej pojmovej mapy sú $\mathrm{v}$ jednoduchosti a účelnosti (hravost', neobmedzená možnost' kreslit' a tvorit' na papieri). Na strane druhej, elektronická mapa je vel'mi interaktívna, umožňuje zmeny a využívajú sa moderné technológie.

Siedma otázka overovala hypotézu $\mathrm{H}_{7}$ (žiaci uprednostňujú pri tvorbe pojmovej mapy viac prácu v skupine ako samostatnú prácu, prácu vo dvojici alebo ked' ich vytvára učitel'). Hypotéza sa ako-tak potvrdila, najradšej v skupine pracuje $34 \%$ žiakov, necelých $30 \%$ však uprednostňuje prácu učitel'a, necelých $28 \%$ preferuje samostatnú prácu a necelých $9 \%$ prácu vo dvojici. Žiaci vyjadrili vysoké percento uprednostňovania pojmových máp vytváraných učitel’om. Spoliehali sa na kvalitný výtvor, ktorý im umožní dosiahnut pri malej námahe efektívne výsledky. Vytvárat' pojmové mapy nemusí byt' len individuálna záležitost'. Jednotlivci môžu profitovat' zo spojenia viacerých síl a vzájomnej spolupráce. Z psychologického hl'adiska vnáša spolupráca žiakov do učenia dynamiku (Mareš, 2011). Zaujímavé je relatívne vysoké percento vytvárania vlastnej pojmovej mapy. Pravdepodobne ich presadzujú individuálnejšie založené povahy so zodpovednostou za svoje výsledky.

Ôsma otázka zist'ovala obl'úbenost' vyučovacej témy na hodine. Medzi prvými troma témami neboli vel'ké rozdiely (od 10 do $18 \%$ ). Najviac sa páčila téma obyvatel'stvo Ázie (18\%). Počas nej si vytvárali vlastné pojmové mapy z textu, pričom pracovali v skupinách.

Deviata a desiata otázka overovala hypotézu $\mathrm{H}_{5}$ (žiaci vytvárajú pojmové mapy viac na predmete geografia ako na iných predmetoch). $Z$ odpovedí vyplynulo potvrdenie tejto hypotézy. Vyše $93 \%$ pojmových máp sa vytvára na geografii, zvyšok na slovenskom jazyku a biológii.

V poslednej dotazníkovej otázke mali žiaci označit’ vety, s ktorými súhlasia v kontexte s prácami na pojmových mapách. Mohli vybrat' viac viet. Pre viac ako $51 \%$ žiakov sú pojmové mapy prehl'adné a $59 \%$ vyjadrilo radost' s prácou s mapami. Pomoc pojmových máp pre zapamätaní si učiva privítalo až $70 \%$ žiakov. Podl'a názoru vyše 46 \% žiakov sa pri vytváraní pojmovej mapy v skupine učí komunikovat', dohodnút' sa a spolupracovat'. Neprehl'adnost' obsahu pojmových máp vyjadrilo vyše $10 \%$ žiakov. Rovnaký počet vyjadril aj svoj negatívny postoj $\mathrm{k}$ práci s pojmovými mapami. $Z$ celkového počtu $34 \%$ žiakov uviedlo, že mapy vytvárajú len ked' musia.

Na základe prieskumu, analýzy žiackych produktov a dotazníka sa môže práca $\mathrm{s}$ pojmovými mapami zaradit' $\mathrm{k}$ efektívnym vyučovacím metódam. Žiaci experimentálnej skupiny používajúci pojmové mapy dosiahli vo väčšine skúmaných prípadov lepšie výsledky ako žiaci kontrolnej skupiny. Pri práci s pojmovými mapami bol preukázaný aj rozvoj čitatel'skej gramotnosti, podporila sa skupinová práca aj individuálny prístup k riešeniu problémov. Pojmové mapy umožňujú vyniknút' aj slabším žiakom. V podstate podl'a Müllera (Müller, 2013), pojmové mapy pomáhajú $\mathrm{k}$ lepšiemu využívaniu mozgu, pretože spájajú informácie, znázorn̆ujú vzt’ahy a vizualizujú myšlienky. 


\section{Pod'akovanie}

Príspevok bol spracovaný v rámci projektu KEGA č. 039UMB-4/2018 „, Geografia Afriky, premeny a perspektivy: metódy výučby a učebnica “.

\section{Literatúra}

BUZAN , T. 2007. Mentální mapování. Praha: Portál s.r.o., 2007. 168 s. ISBN 978-80-7367-200-3.

DRBOHLAV, D. 1991. Mentální mapa ČSFR, definice, aplikace, podmínenost. In Sbornik Československé geografické společnosti. ISSN 0231-5300, 1991, roč. 96, č. 1, s. 163-175.

ČERNÝ, M. - ČERNÁ, M. 2011. 7 tipů, jak použít myšlenkové mapy [online]. Metodický portál RVP : Základní vzdělávání. 2011. [cit. 2018-8-12]. Dostupné na internete: <http://clanky.rvp.cz.clanek/c/G/13181/7-TIPU-JAK-POUZITMYSLENKOVE-MAPY.htm>. ISSN 1802-4785.

FISHER, R. 1997. Učíme děti myslet a učit se: praktický průvodce strategiami vyučování. 1. vyd. Praha: Portál s.r.o., 1997. 172 s. ISBN 978-80-262-0043-7.

GAVORA, P. 2000. Úvod do pedagogického výzkumu. Brno: Paido, 2000. 207 s. ISBN 80-85931-79-6.

GREGOROVÁ, B. 2009. Mentálna mapa ako didaktická pomôcka výučby geografie na modelovom území Nizkych Tatier: Rigorózna práca. Banská Bystrica: Univerzita Mateja Bela, 2009. 142 s.

JIRÁSEK, I. 2015. Využití mentálních map v pedagogickém výzkumu: metodologické souvislosti. In Pedagogika. ISSN 2336-289, 2015, roč. 65, č. 1, s. 57-74.

KAROLČÍK, Š. - MURTINOVÁ, L. 2013. Úspešnost' zaradenia pojmových máp do programu výučby geografie na nižšom stupni sekundárneho vzdelávania (1. čast'). In Moderní vyučování. ISSN 1211-6858, 2013, roč. 18, č. 5-6, s. 40-41.

KAROLČÍK, Š. - MURTINOVÁ, L. 2014a. Pojmové mapy v programe výučby regionálnej geografie. In Geografia. ISSN 1335-9258, 2014, roč. 22, č. 1, s. 1725.

KAROLČÍK, Š. - MURTINOVÁ, L. 2014b. Pojmové mapy a nástroje na ich tvorbu. In Geografické rozhledy. ISSN 1210-3004, 2014, roč. 23, č. 4, s. 12-14.

MÜLLER, H. 2013. Myšlenkové mapy: jak zlepšit své myšlení, pamět', koncentraci a kreativitu. Praha: Grada, 2013.112 s. ISBN 978-80-247-5057-6.

PROKŠA, M. 2007. Pojmové mapy ako výskumný a diagnostický prostriedok v chemickom vzdelávaní. In Inovačné trendy v prírodovednom vzdelávaní. Trnava: Trnavská univerzita, 2007. ISBN 978-80-8082-131-9, s. 98-101.

PROKŠA, M. - HELD, L. - TÓTHOVÁ, A. a kol. 2008. Metodológia pedagogického výskumu ajeho aplikácia vdidaktikách prírodných vied. Bratislava: UK, 2008. 229 s. ISBN 978-80-223-2562-2. 
TUREK, I. 1996. Učitel' a pedagogický výskum. Bratislava: Metodické centrum v Bratislave, 1996. 137 s. ISBN 80-7164-173-1.

\section{APPLICATION OF MIND MAPS IN GEOGRAPHY AT PRIMARY SCHOOLS}

\section{Summary}

Mind maps as a teaching method have been used since the 1950s (Drbohlav, 1991, Fisher, 1997, Buzan, 2007, Prokša, 2007, Prokša et al., 2008, Černý, Černá, 2011, Karolčík, Murtinová, 2013, 2014a, 2014b and others). They rank among activating methods based on planning, organising, and managing teaching geography by means pupils' cognition. Mind maps are creative thinking tools, considering the fact that the creative process is just as important as the result.

The aim of the paper was to apply methodological proposals regarding geography classes at which mind maps were used. Furthermore, we wanted to evaluate their efficiency in comparison with traditional teaching methods. We were also interested in pupils' opinions of using mind maps in geography classes. The main research method used was pedagogical experiment realised in two groups and performed under natural school conditions. One hundred sixth grade primary school pupils were involved in the research. They were divided into two groups the experimental group and the control group. The experiment was performed in the school years 2016/2017 and 2017/2018.

Before starting the research, methodological proposals for geography classes were created and pupils were supposed to take notes in the form of mind maps (topic: South Africa). Mind maps were also used to revise pupils' knowledge through group work (topic: the surface area of Asia), to learn new subject matter (topic: the waters of Asia), and group work with specialised text (topic: the population of Asia). Subsequent empirical research was realised in the form of an electronic questionnaire.

Based on the $5^{\text {th }}$ grade pupils' learning achievements in geography, pupils were divided into two groups - the experimental and the control ones. In existing school conditions it was not possible to create two equal groups based on the average grades, since statistically significant difference was present between them. Subsequently, the class with the lower grades became the experimental group (Turek 1996). Before pupils started using mind maps, one geography class was focused on explaining the essence of creating mind maps in traditional paper form or using computer programmes XMind or MindMaple Lite.

The methodological proposals were applied as a teaching/learning method for the following topics: South Africa; surface area, waters, and population of Asia. After the classes, pupils filled in electronic questionnaires and thus they provided us with their opinions and attitudes towards using mind maps in learning 
geography. They also evaluated the effectiveness of mind maps utilisation in learning process. The research and subsequent analysis of pupils' questionnaires and assignments showed that mind maps can generally be considered an efficient teaching/learning method. The experimental group achieved significantly better learning results than the control group. In most cases, pupils in the experimental group scored better than their peers in the control group. To conclude, using mind maps in geography classes promote group work, improve reading skills and key competences of pupils.

\section{Doc. RNDr. Alfonz Gajdoš, PhD.}

Katedra geografie a geológie

Fakulta prírodných vied

Univerzita Mateja Bela v Banskej Bystrici

Tajovského 40, 97401 Banská Bystrica

E-mail: alfonz.gajdos@umb.sk

\section{Mgr. Dominika Majcherová}

Cirkevná základná škola Romulda Zaymusa

Romulda Zaymusa 2205/3, 01001 Žilina

E-mail: majcherová.d@gmail.com 